\title{
Hakikat KB-RA. Perwanida Ketintang Surabaya dalam Mengajarkan Buku Materi Bahasa Arab-Inggris pada Kelompok A
}

\author{
Imam Syafi'i ${ }^{1}$, Alfian Nuril Laily Abror ${ }^{2}$ \\ ${ }^{1,2}$ UIN Sunan Ampel Surabaya
}

DOI : https://doi.org/10.15642/jeced.v2i1.577

\begin{abstract}
The purpose of this study to describe the reasons for KB-RA. Perwanida Ketintang Surabaya teaches Arabic-English of material books to group A. The problem this study how many people ask about the reason the institution teaches Arabic-English material books. The method in this study uses the type of qualitative research that describes why KB-RA. Perwanida Ketintang Surabaya teaches Arabic-English language material books to group A. The data collection in this study are observation, interviews and documentation. The results of the study are KB-RA. Perwanida reasoned because it could develop the development of foreign language of children in accordance with the age stage, creating a fun and interesting learning atmosphere, making it easier for students to learn Arabic and English at the next educational level and can train cognitive development in early childhood. In addition, children also have more time to learn Arabic and English, children will Moore quickly understand the language Boeing studied which is very influential in the next stage of language development, children will be more proficient in katering the mother tongue. Children will have the opportunity to learn Arabic and English again St the elementary or secondary school level, this book is very interesting for young children and makes it easy for for teachers to deliver learning material.
\end{abstract}

Article Info

Article history:

Received: 01062020

Accepted: 03062020

Published online: 15062020

Keywords:

Itself

Teaching

arabic-english material books

\begin{abstract}
Abstrak
Tujuan dalam penelitian ini adalah untuk mendeskripsikan alasan KBRA. Perwanida Ketintang Surabaya mengajarkan buku materi Bahasa Arab-Inggris pada kelompok A. Permasalahan dalam penelitian ini adalah banyaknya masyarakat yang menanyakan perihal alasan lembaga tersebut mengajarkan buku materi Bahasa Arab-Inggris. Metode dalam penelitian ini menggunakan jenis penelitian kualitatif yaitu mendeskripsikan mengapa KB-RA. Perwanida Ketintang Surabaya mengajarkan buku materi Bahasa Arab-Inggris pada kelompok A. Teknik pengumpulan data yang digunakan pada penelitian ini yaitu observasi, wawancara dan dokumentasi. Hasil dari penelitian tersebut KB-RA. Perwanida beralasan karena dapat mengembangkan perkembangan bahasa asing anak usia di sesuai dengan tahap usianya, menciptakan suasanya belajar yang menyenangkan dan menarik, memudahkan siswa untuk belajar Bahasa Arab dan Inggris pada tingkat pendidikan selanjutnya dan dapat melatih perkembangan kognitif anak usia dini. Selain itu, anak juga memiliki lebih banyak waktu untuk belajar Bahasa Arab dan Bahasa Inggris, anak akan lebih cepat memahami bahasa yang sedang dipelajarinya yang sangat berpengaruh pada tahap perkembangan bahasa selanjutnya, anak akan lebih mahir dalam menguasai bahasa ibu. Anak akan memiliki kesempatan belajar Bahasa Arab dan Bahasa Ingris lagi di tingkah sekolah dasar ataupun menengah, bukui ini sangat menarik untuk AUD dan memudahkan guru dalam menyampaikan materi pembelajaran.
\end{abstract}

\section{Informasi Artikel \\ Riwayat Artikel \\ Revisi terakhir: 01062020 \\ Diterima: 03062020 \\ Publikasi online: 15062020 \\ Kata kunci: \\ hakikat \\ mengajar \\ buku materi bahasa arab-inggris}




\section{PENDAHULUAN}

Pendidikan sangatlah dibutuhkan suatu negara dengan bertujuan untuk memajukan negara tersebut. Pendidikan merupakan proses sistematis yang terjadi setiap saat untuk mengangkat harkat dan martabat manusia secara keseluruhan (Andriana et al., 2017). Pendidikan tersebut harus merata, artinya bahwa semua warga Negara Indonesia berhak untuk merasakan nikmatnya mendapat pendidikan, sehingga semua rakyat Indonesia dapat mengetahui, mengeksplorasi dan memanfaatkan potensi dan dapat memiliki keterampilan yang dibutuhkan dirinya, masyarakat maupun negara. Jika setiap individu mengetahui setiap potensi yang ada pada dirinya, maka individu tersebut akan mampu menempatkan dirinya sesuai potensi dan memiliki tujuan hidup. Di Indonesia, dunia pendidikan khususnya terhadap pendidikan anak usia dini (PAUD) telah mendapatkan simpati dari berbagai pihak yang beberapa tahun terakhir ini pemerintah memperhatikan PAUD agar lebih luas dan merata di Indonesia.

PAUD adalah suatu proses pendidikan yang memfokuskan kepada peletakan fondasi menuju perkembangan dan pertumbuhan baik koordinasi kecerdasan emosi, kecerdasan jamak, kecerdasan spiritual, motorik kasar dan motorik halus. Masa anak usia dini ini merupakan (golden age) di mana pada masa ini anak mengalami perkembangan dan pertumbuhan yang cepat sekali, dan di masa ini tidak pernah terulang lagi pada masa mendatang (Lestariningrum, 2017). Dalam masa perkembangan anak pada usia 2 sampai 7 tahun merupakan masa yang paling aktif khususnya dalam perkembangan bahasa dan kognitif.

Perkembangan kognitif adalah suatu susunan yang akan menggambarkan kemampuan mental seseorang yang meliputi kemampuan memecahkan masalah, pemikiran yang abstrak dan belajar dari sebuah pengalaman (Anggraini, Wardah; Putri, 2019). Selaras dengan pendapat Salmiati yang dikutip oleh Anggraini dan Putri mengatakan bahwa perkembangan kognitif merupakan kemampuan seseorang untuk berpikir, dalam memahami masalah, mengingat segala yang ada di sekitarnya dan melibatkan proses mental meliputi; penyerapan, pengorganisasian dan mencerna segala bentuk informasi yang didapat (Anggraini, Wardah; Putri, 2019, p. 105).

Indikator pada perkembangan bahasa secara keseluruhan harus diajarkan kepada anak sebelum berakhirnya masa sensitif (Arumsari et al., 2017). Di samping itu, pembelajaran bahasa juga sangat berpengaruh pada potensi perkembangan kognitifnya. Jika kemampuan anak untuk berpikir dan mengingat segala yang ada di sekitar lingkungannya dapat dilakukan dengan baik, maka anak dengan mudah menerima berbagai bahasa dari lingkungannya. Pada waktu masa sensitif, anak akan cepat menerima rangsangan. Rangsangan tersebut sangat cocok dengan PAUD, dimana pembelajarannya disesuaikan dengan perkembangan dan pertumbuhan anak sehingga anak siap untuk mendapat pendidikan selanjutnya, dimana pendidikan sejak dini tersebut sangat berpengaruh bagi pertumbuhan anak selanjutnya untuk beradaptasi dan berinteraksi dengan lingkungan sekitarnya.

Manusia merupakan makhluk sosial yang membutuhkan interaksi dengan lingkungan yang ada disekitarnya. Kegiatan interaksi tersebut bisa dilakukan melalui bahasa yang digunakan sebagai alat komunikasi yang dapat dimengerti oleh masyarakat yang ada disekitarnya. Menurut Badudu mengungkapkan bahasa merupakan suatu alat komunikasi yang dilakukan masyarakat yang terdiri dari setiap individu sehingga dapat menyatakan perasaan, gagasan maupun keinginannya (Dhieni, 2011). Dardjowidjojo dan Unika (2012) mengungkapkan bahwa bahasa adalah susunan yang teratur berupa simbol lisan abitrer yang dipakai oleh masyarakat untuk saling berhubungan dan memengaruhi, 
yang berdasarkan adat istiadat mereka. Masyarakat dalam menggunakan bahasa sebagai alat untuk berinteraksi dan mengidentifikasi diri sendiri sebagai susunan lambang bunyi yang bersifat manasuka. Tetapi bahasa tidak hanya sekedar lambang bunyi saja, bahasa isyarat juga dapat dimengerti oleh masyarakat dimana bahasa isyarat tersebut tidak menghasilkan bunyi melainkan sebuah gerakan yang dapat dimengerti oleh sebagian orang tertentu saja.

Beberapa keterampilan bahasa terdiri dari keterampilan mendengarkan, keterampilan berbicara dan keterampilan membaca. Pembelajaran bahasa untuk anak usia dini (AUD) atau tahap awal dapat dimulai dengan tahap keterampilan mendengarkan. Jika anak sering mendengar kosakata atau kalimat yang sedang dipelajari, maka anak akan lebih mudah mengingat kosakata atau kalimat tersebut. kosakata atau kalimat yang sering di dengar oleh anak akan terekam di dalam otak sehingga anak mudah mengingat dan ingatan tersebut akan muncul saat diperlukan. Anak akan memiliki keterampilan berbicara ketika sudah familiar dengan kosakata yang sedang dipelajarinya, dan kemudian anak di latih untuk membaca.

Keterampilan membaca dilakukan hingga batas kemampuan yang mengisyaratkan mengulang-ngulang bacaan sehingga menambah pengetahuan dan wawasan baru walaupun yang dibaca berupa objek yang sama (Dardjowidjojo; Jaya, 2012). Pada tahap usia dini, anak di perintahkan untuk membaca sesuai kemampuannya, tidak dipaksa karena sesuatu yang dipaksa akan akan sia-sia. Anak akan merasa tertekan saat dipaksa dan hal tersebut membuat pengetahuan yang dipelajarinya sulit untuk masuk ke memorinya. Anak diajarkan keterampilan membaca secara bertahap di awali dari tahap keterampilan mendengarkan, keterampilan berbicara hingga keterampilan membaca. Salah satu AUD memiliki keterampilan membaca, agar mereka dapat berkomunikasi dan berinteraksi dengan lingkungan sekitarnya. Adapun bahasa yang dipelajari bukan hanya bahasa pertama atau bahasa ibu saja melainkan bahasa kedua salah satunya Bahasa Arab dan Bahasa Inggris.

Hasil dari pra survey yang dilakukan penulis, terdapat masyarakat yang menanyakan alasan KB-RA. Perwanida Ketintang Surabaya mengajarkan buku materi Bahasa Arab-Inggris. Dari hasil penelitian sebelumnya dalam skripsi Alfian Nuril, telah dipaparkan implementasi buku materi Bahasa Arab-Inggris dalam pembelajaran bahasa pada anak usia dini kelompok A di KB-RA. Perwanida Ketintang Surabaya. Selain itu juga dijabarkan tentang kelebihan dan kelemahan buku materi Bahasa Arab-Inggris salah satunya ialah bahwa sekolah ini mampu meciptakan produk sendiri buku ajar materi Bahasa Arab-Inggris agar buku yang digunakan sesuai dengan tahap perkembangan dan karakteristik anak usia dini. Dari penelitian tersebut, masyarakat menanyakan perihal alasan atau hakikat sekolah ini menerapkan buku materi Bahasa Arab-Inggris. Sehingga penulis tertarik untuk membahas rumusan masalah tentang mengapa KB-RA. Perwanida Ketintang Surabaya mengajarkan buku materi Bahasa Arab-Inggris pada kelompok A.

Menurut Permendikbud (Peraturan Menteri Pendidikan dan Kebudayaan Republik Indonesia) Nomor 137 Tahun 2014 Standar Tingkat Pencapaian Perkembangan Anak usia 4-5 tahun, pada lingkup perkembangan bahasa pada sub bab memahami bahasa anak dapat menyimak perkataan orang lain (bahasa ibu atau bahasa lainnya). Sedangkan pada sub bab mengungkapkan bahasa anak mampu menjawab pertanyaan sesuai pertanyaan. Kognitif adalah suatu proses berpikir, yaitu kemampuan individu untuk menghubungkan, menilai dan mempertimbangkan suatu kejadian atau peristiwa. Proses kognitif berhubungan demam tingkat kecerdasan (intelegensi) yang menandai seseorang 
dengan berbagai minat terutama sekali ditujukan kepada ide-ide dan belajar (Susanto, 2011).

Berdasarkan uraian di atas, dari segi perkembangan bahasa anak usia 4-5 tahun sudah mampu menyimak perkataan orang lain/guru dan menjawab pertanyaan dari guru. Kegiatan menyimak dan menjawab pertanyaan sesuai pertanyaan tersebut membutuhkan proses berpikir dan berhubungan dengan tingkat kecerdasan anak. Semakin baik tingkat kecerdasan anak, maka akan semakin cepat anak memahami sesuatu yang berada di sekitarnya. Bukan hanya menyimak saja, melainkan Siwa harus melihat hambar dan teks yang terdapat dalam gambar tersebut. Dalam suatu penelitian mengatakan bahwa, teks yang diperbesar memungkinkan semua anak di kelas untuk melihat dan bereaksi terhadap kata-kata dan gambar-gambar di halaman ketika guru membacakan dengan lantang di depan para siswa (Nambiar, 1993).

Pada era globalisasi yang telah dirasakan pada saat ini, budaya, teknologi dan bidang keilmuan lainnya menjadi pertukaran informasi antar negara. Hal tersebut sebagai peran bahasa yang semakin berkembang. Banyak negara yang tidak menggunakan bahasa asing menyadari pentingnya bahasa asing khususnya Bahasa Arab dan Bahasa Inggris dalam hal ini era globalisasi. (Yuli \& Rachmawati, 2014). Seperti yang telah diketahui bahwa Bahasa Inggris merupakan Bahasa Internasional pertama di dunia yang menguasai era informasi ke seluruh dunia. (Tyaningsih, 2016). Hampir seluruh negara di dunia menyampaikan informasi menggunakan bahasa asing khususnya Bahasa Arab dan Bahasa Inggris sebagai bahasa yang dapat menyatukan manusia yang berasal dari berbagai belahan dunia.

Pembelajaran Bahasa Inggris sangat tepat jika diberikan sedini mungkin. Hal ini ditambahkan oleh Tolsikhina yang dikutip oleh Annisa Rachmani Tyaningsih (2016) mengenai tepatnya memberikan pelajaran Bahasa asing untuk anak usia dini dengan menyatakan beberapa alasan, yaitu, (1) belajar bahasa asing yang dimulai lebih awal akan memiliki waktu yang lebih maksimal untuk belajar. Semakin cepat memulai, akan semakin banyak waktu untuk belajar, (2) saat ini perkembangan linguistik anak usia dini sedang pada tahap yang sangat baik untuk dimanfaatkan sebagai dasar dalam perkembangan linguistik selanjutnya, (3) kemampuan anak usia dini untuk menggunakan bahasa ibunya akan lebih baik jika anak mendapat rangsangan bahasa asing sejak usia dini dan (4) anak akan memiliki kesempatan lebih baik untuk mempelajari bahasa asing yang kedua di sekolah menengah apabila anak yang belajar bahasa asing pertamanya di pra-sekolah atau tingkat sekolah dasar.

Bahasa asing khususnya Bahasa Arab dan Bahasa Inggris diajarkan di sekolah bermanfaat untuk ilmu pengetahuan, selain sebagai alat komunikasi. Pembelajaran bahasa sebaiknya diberikan sejak dini. Selain bahasa ibu yang harus dikenalkan kepada anak juga perlu dikenalkan Bahasa Arab dan Bahasa Inggris sebagai bahasa kedua. Pengenalan bahasa asing sejak anak usia dini dapat membuat anak familiar dengan Bahasa Arab dan Bahasa Inggris. Semakin anak familiar dengan Bahasa Arab dan Bahasa Inggris, semakin mudah pula anak tersebut meneruskan pembelajaran bahasa asing pada tingkat yang lebih tinggi, yaitu tingkat sekolah dasar. Selain itu, anak akan mendapatkan keuntungan yang lebih dengan belajar Bahasa asing sejak dini, seperti menjadi lebih percaya diri, karena memiliki skill yang lain yang tidak dimiliki oleh anak-anak lain (Muid, 2015).

Dalam mempelajari suatu hal diperlukan buku ajar yang dapat menunjang pembelajarannya. Andi Prastowo menjelaskan bahwa tujuan buku ajar, yaitu, 
menyediakan materi pembelajaran yang menarik bagi siswa dan memberi kemudahan bagi guru dalam menyampaikan materi pembelajaran. (Mujiarti, 2014).

\section{METODE}

Metode penelitian ini menggunakan jenis penelitian kualitatif deskriptif. Penelitian kualitatif yaitu suatu pengamatang kepada orang di dalam lingkungannya, melakukan interaksi kepada mereka, berusaha memahami bahasa dan tafsiran mereka mengenai dunia sekitarnya (Rujakat, 2018). Menurut Yusuf penelitian kualitatif deskriptif adalah penelitian yang mengutamakan penelitian data atau peristiwa yang nyata yang berdasarkan pada proses yang telah dieksploitasikan dan diungkapkan oleh para responden dan data yang dikumpulkan berupa gambar, kata-kata dan kebanyakan bukan angka-angka. Walaupun ada angka, akan tetapi sifatnya hanya sebagai penunjang saja (Mawarti, 2018).

Lokasi dalam penelitian ini di KB-RA. Perwanida Ketintang Surabaya. Subjek dalam penelitian ini adalah kepala sekolah, guru dan siswa kelompok A. Dalam pengumpulan data penelitian ini penulis menggunakan tiga sumber data yakni; observasi, wawancara dan dokumentasi. Observasi dilakukan melalui observasi non partisipan yakni pengamatan yang dilakukan secara langsung ke lapangan dan peneliti hanya sebagai pengamat serta tidak terlibat langsung pada kegiatan sumber data. (Chairunnissa, 2017). Pelaksanaan observasi non partisipan, dilakukan dengan cara turun langsung kelokasi penelitian yakni di KB-RA. Perwanida Ketintang Surabaya dan tidak terlibat secara langsung pada kegiatan sumber data. Peneliti hanya sebagai pengamat peristiwa yang ada sesuai situasi alami.

Wawancara merupakan pembicaraan yang dilakukan oleh dua pihak yaitu pewawancara mempersiapkan dan mengajukan pertanyaan dan terwawancara menjawab atas pertanyaan tersebut yang bertujuan untuk bertukar informasi dan ide melalui tanya jawab. Peneliti menggunakan wawancara terstruktur, karena peneliti sudah mengetahui tentang informasi yang dibutuhkan atau data yang diperoleh. Dalam teknik ini, peneliti sudah menyediakan instrumen penelitian berupa pertanyaan-pertanyaan tertulis di mana peneliti telah mengetahui jawaban alternatifnya. (Chairunnissa, 2017). Dokumentasi yang penulis dapatkan yaitu data-data sekolah, perangkat pembelajaran dan foto kegiatan buku materi Bahasa Arab-Inggris digunakan.

Instrumen pada penelitian ini yakni peneliti sendiri. Instrumen tersebut meliputi observasi, wawancara dan dokumentasi. Setelah data berhasil dikumpulkan, kemudian melakukan analisis yang mengacu pada model analisis Miles and Huberman yang meliputi reduksi data, penyajian data dan menarik kesimpulan. Teknik keabsahan data menggunakan credibility, transferability, dependability dan confirmability. Credibility dilakukan melalui triangulasi metode dan sumber (Chairunnissa, 2017).

\section{HASIL PENELITIAN DAN ANALISIS}

Penelitian kualitatif dilakukan untuk mendeskripsikan temuan-temuan hasil penelitian. Metode dokumentasi dapat dikatakan sebagai penguat hasil data yang telah ditemukan dan untuk melengkapi data yang telah didapat saat wawancara dan observasi. Tempat pelaksanaan penelitian ini yaitu KB-RA. Perwanida Ketintang Surabaya. Sumber data berasal dari kepala sekolah, guru dan siswa kelompok A.

Terdapat beberapa alasan KB-RA. Perwanida mengajarkan buku materi Bahasa Arab-Inggris. Di antara alasan tersebut didapat melalui observasi, wawancara dan 
dokumentasi yang sudah penulis analisis. Sedangkan metode pengumpulan data tersebut sesuai dengan realita dan fakta yang terjadi di lapangan dengan apa adanya.

Awal mula penulis melakukan penelitian di KB-RA. Perwanida Ketintang Surabaya yaitu untuk mengamati hakikat KB-RA. Perwanida Ketintang Surabaya dalam mengajarkan buku materi Bahasa Arab-Inggris pada kelompok A. Penelitian kualitatif yang digunakan pada penelitian ini yakni untuk menarik benang merah dari hasil observasi kegiatan pelaksanaan penerapan buku ajar materi Bahasa Arab-Inggris, sedangkan wawancara dilakukan bersama kepala sekolah dan guru dan didukung dengan data dokumentasi. Setelah semua data yang diperlukan telah terkumpul, kemudian penulis melakukan analisis data. Pada penelitian ini difokuskan pada mengapa alasan KB-RA. Perwanida Ketintang Surabaya mengajarkan buku materi Bahasa Arab-Inggris pada kelompok A. Dari hasil penelitian yang di dapat melalui wawancara, observasi dan dokumentasi akan dipaparkan sebagai berikut.

Berdasarkan wawancara bersama kepala sekolah, terdapat kecenderungan masyarakat terhadap penguasaan bahasa asing anak-anak yang mengakibatkan lembaga ini memasukkan pembelajaran Bahasa Arab dan Inggris ke dalam kegiatan belajar mengajar. Karena anak mau belajar, jika mereka berada pada suasana yang menyenangkan terlebih dahulu agar anak mau memperhatikan dan mendengarkan guru serta, materi pembelajaran yang disampaikan bisa diterima dan dimengerti. Agar materi pembelajaran Bahasa Arab dan Inggris yang guru sampaikan dapat diterima dan dimengerti oleh anak, maka dalam proses pembelajaran bahasa diperlukan sebuah buku materi Bahasa Arab-Inggris.

Selain itu, kepala sekolah juga mengatakan bahwa pengajaran buku materi Bahasa Arab-Inggris di RA. Perwanida dikarenakan banyak siswa yang masih sangat minim pengetahuan dan kosakata Bahasa Arab maupun Bahasa Inggris. Bahasa Arab merupakan bahasa al-Qu'an dan hadis, dan RA. Perwanida sebagai lembaga yang berbasis Islam membuat lembaga ini menerapkan pembelajaran Bahasa Arab. Selain itu, Bahasa Inggris yang dikenal sebagai Bahasa Internasional dan lembaga pendidikan selanjutnya seperti MI juga sudah banyak menerapkan Bahasa Inggris yang menyebabkan KB-RA. Perwanida mempunyai keunikan tersendiri untuk menarik perhatian minat para orang tua untuk memasukkan putra-putrinya sekolah di RA. Perwanida Ketintang Surabaya. Kecenderungan masyarakat terhadap penguasaan bahasa asing mengakibatkan lembaga ini memasukkan pembelajaran Bahasa Arab dan Inggris ke dalam kegiatan belajar mengajar. Hal ini sebagaimana dikemukakan salah satu guru bahwa anak yang telah memasuki pendidikan SD/MI menganggap mudah pembelajaran Bahasa Arab dan Inggris karena sudah familiar dengan bahasa tersebut.

Penerapan pembelajaran Bahasa Arab dan Inggris untuk AUD ini membutuhkan suasana yang menyenangkan bagi anak karena pembelajaran bagi AUD ini memang memiliki perbedaan dengan pembelajaran bagi anak yang berusia sekolah. Untuk menciptakan suasana yang menarik tersebut, KB-RA. Perwanida Ketintang Surabaya membuat buku materi Bahasa Arab-Inggris sendiri agar materinya sesuai dengan karakteristik anak usia dini.

Berdasarkan wawancara bersama guru, guru merasa lebih dipermudah dengan adanya buku tersebut. Guru tidak perlu repot-repot menyiapkan materi pembelajaran karena semua materi pembelajaran Bahasa Arab dan Bahasa Inggris sudah terdapat dalam buku tersebut. Pengajaran Bahasa Arab dan Bahasa Inggris berdampak positif kepada para siswa, dimana siswa dapat menguasi bahasa asing yang menguasai era informasi ke seluruh dunia pada zaman globalisasi ini. Pemberian stimulasi Bahasa Arab dan Bahasa 
Inggris sangat baik diberikan sejak usia dini karena anak akan lebih cepat menerima stimulasi-stimulasi yang diberikan oleh guru. Anak juga dapat memiliki senggang waktu yang cukup lama untuk mempelajari Bahasa Arab dan Bahasa Inggris sehingga mereka akan lebih cakap dalam berbicara bahasa asing tersebut. Tentunya pemberian stimulasi Bahasa Arab dan Bahasa Inggris tersebut sesuai dengan standar tingkat pencapaian perkembangan anak usia dini.

Buku materi Bahasa Arab-Inggris merupakan buku yang digunakan untuk menambah kosakata anak usia dini baik Bahasa Arab dan Inggris yang berukuran F4. Buku ini berisi gambar nama-nama anggota keluarga, anggota tubuh, tumbuhan, hewan, alat-alat tulis, transportasi dan sebagainya yang di sesuaikan dengan tema PAUD disertai teks dalam Bahasa Arab dan Bahasa Inggris. Teks tersebut berupa teks Bahasa Arab dan Bahasa Inggris yang dapat mengenalkan huruf latin dan huruf hijaiyah ke pada anak. Anak akan mengetahui terdiri dari huruf apa saja yang terdapat pada suatu kosakata atau kalimat.

Buku ini dibuat secara menarik agar anak tertarik dan dapat melatih perkembangan Bahasa Arab maupun bahasa Inggris yang sesuai dengan tahap perkembangan anak usia dini. Hal ini terbukti dari hasil observasi peneliti bahwa ketika guru menanyakan dan menunjuk salah satu gambar di dalam buku materi Bahasa Arab-Inggris, para siswa langsung menjawab menggunakan Bahasa Arab atau Inggris, sehingga anak dapat menambah kosakata Bahasa Arab dan Inggris sesuai jadwalnya.

\section{PEMBAHASAN}

Dari data deskriptif hasil observasi, dokumentasi dan wawancara di atas, dapai ditarik benang merah bahwa KB-RA. Perwanida mengajarkan buku materi Bahasa ArabInggris dengan suasana yang menyenangkan, melalui buku yang dibuat sendiri dengan model yang unik sehingga mampu menarik perhatian anak-anak. Buku ini dibuat bertujuan agar siswa termotivasi dan semangat untuk belajar. Hal ini sesuaii dengan pendapat Moeslichatoen dalam Anggraini dan Putri bahwa cara belajar anak adalah dengan bermain seraya belajar, namun hal tersebut harus dengan suasana yang kondusif dan juga dibutuhkan keaktifan anak, di samping itu penyajian materinya pun harus dikemas sedemikian rupa, sehingga mampu menarik perhatian dan informative, agar anak dapat berlatih dan belajar dalam suasana yang menyenangkan tanpa meninggalkan tujuan pembelajaran tersebut (Anggraini, Wardah; Putri, 2019).

KB-RA. Perwanida ingin menambah kosakata Bahasa Arab dan Inggris siswa sesuai tahap perkembangannya. Siswa dapat menyimak atau mendengarkan penjelasan guru yang sedang menjelaskan tentang kosakata atau kalimat Bahasa Arab dan Inggris selain itu siswa dilatih untuk mengulang kosakata atau kalimat yang diucapkan oleh guru serta menjawab pertanyaan guru sesuai pertanyaan yang diajukan oleh seorang guru. Hal ini sesuai dengan Permendikbud (Peraturan Menteri Pendidikan dan Kebudayaan Republik Indonesia) Nomor 137 Tahun 2014 Standar Tingkat Pencapaian Perkembangan Anak usia 4-5 tahun, pada lingkup perkembangan bahasa di mana pada sub bab memahami bahasa anak dapat menyimak perkataan orang lain (bahasa ibu atau bahasa lainnya). Sedangkan pada sub bab mengungkapkan bahasa anak mampu menjawab pertanyaan sesuai pertanyaan yang diajukan.

Di pendidikan anak usia dini pengembangan kognitif dikenal dengan pengembangan daya pikir. Pengembangan kognitif ditujukan agar anak mampu mengeksplorasi dunia sekitarnya melalui pancaindranya sehingga kemampuan visual, auditor, aritmetika, sains sederhana, geometri dan kinestetik dapat berkembang dengan 
baik (Pangastuti, 2019). Ketika siswa berusaha menyimak dan menjawab pertanyaan guru dengan tepat tentunya membutuhkan suatu proses berpikir yang berhubungan dengan perkembangan kognitif anak. Hal ini selaras dengan ungkapan Susanto (2011) bahwa kognitif adalah suatu proses berpikir, yaitu kemampuan individu untuk menghubungkan, menilai dan mempertimbangkan suatu kejadian atau peristiwa. Proses kognitif berhubungan dengan tingkat kecerdasan (intelegensi) yang menandai seseorang dengan berbagai minat terutama sekali ditujukan kepada ide-ide dan belajar. Bahasa sebagai alat untuk mengekspresikan diri, berpikir dan berkomunikasi. Bahasa berhubungan dengan sarana komunikasi dengan menyimbolkan pikiran dan perasaan untuk mengungkapkan makna kepada orang lain. perkembangan bahasa dan perkembangan kognitif memiliki hubungan yang begitu erat. Bahasa memiliki peranan yang sangat penting terhadap suatu proses berpikir anak. Dengan menggunakan bahasa anak akan lebih mudah mengerti suatu informasi yang didapat maupun kemampuan yang baru. Kemampuan bahasa benak dipengaruhi oleh kapasitas kemampuan kognitifnya. Besarnya kesempatan proses belajar yang berasal dari lingkungannya sangat mempengaruhi kemampuan berbahasa anak (Sa'ida, 2018).

Semakin anak familiar dengan Bahasa Arab dan Bahasa Inggris, semakin mudah pula anak tersebut meneruskan pembelajaran bahasa asing pada tingkat yang lebih tinggi, yaitu tingkat sekolah dasar. Selain itu, anak akan mendapatkan keuntungan yang lebih dengan belajar Bahasa asing sejak dini, seperti menjadi lebih percaya diri, karena memiliki skill yang lain yang tidak dimiliki oleh anak-anak lain (Muid, 2015). Hal ini sejalan dengan perkataan guru bahwa siswa yang sudah belajar buku materi Bahasa ArabInggris di KB-RA. Perwanida dan sudah masuk MI/SD menganggap mudah mempelajari Bahasa Arab dan Inggris karena sudah familier dengan bahasa tersebut. Kecenderungan masyarakat terhadap penguasaan bahasa asing mengakibatkan KB-RA. Perwanida memasukkan pembelajaran Bahasa Arab dan Inggris ke dalam kegiatan belajar mengajar sehingga menjadi daya tarik tersendiri bagi para orang tua untuk memasukkan anaknya sekolah di lembaga tersebut.

Pada era globalisasi yang telah dirasakan pada saat ini, budaya, teknologi dan bidang keilmuan lainnya menjadi pertukaran informasi antar negara. Hal tersebut sebagai peran bahasa yang semakin berkembang. Banyak negara yang tidak menggunakan bahasa asing menyadari pentingnya bahasa asing khususnya Bahasa Arab dan Bahasa Inggris dalam hal ini era globalisasi (Yuli \& Rachmawati, 2014). Seperti yang telah diketahui bahwa Bahasa Inggris merupakan Bahasa Internasional pertama di dunia yang menguasai era informasi ke seluruh dunia (Tyaningsih, 2016). Hampir seluruh negara di dunia menyampaikan informasi menggunakan bahasa asing khususnya Bahasa Arab dan Bahasa Inggris sebagai bahasa yang dapat menyatukan manusia yang berasal dari berbagai belahan dunia. Mengajarkan Bahasa Inggris sebagai bahasa asing lebih tepat, karena menurut A Faidal Bahasa Internasional yaitu Bahasa Inggris memiliki fungsi yang sangat penting dalam hidup pada masa sekarang karena bahasa tersebut menjadi suatu kewajiban untuk dipelajari dalam berbagai lapisan masyarakat, baik bagi pelajar maupun masyarakat umum. Dalam aspek pergaulan, Bahasa Inggris selalu dijumpai baik secara lisan maupun tulisan. Selain itu, Bahasa Inggris juga merupakan bahasa yang digunakan sebagai media komunikasi dan sebagai bahasa internasional pertama yang digunakan untuk berinteraksi dengan orang lain di seluruh dunia (Y. V. Uzer, 2019).

Hal ini sesuai dengan teori di atas, bahwa KB-RA. Perwanida Ketintang Surabaya ingin melatih para siswanya untuk menguasi bahasa asing sejak dini. Memang untuk melatih anak bahasa asing sejak dini tidak langsung bisa menyampaikan informasi ke 
seluruh dunia. Akan tetapi kegiatan tersebut dapat melatih dan memberi pengetahuan dasar kepada anak usia dini sesuai tahap usianya serta dapat melatih anak. Secara tidak langsung, anak juga akan familiar dengan teks Bahasa Arab dan Bahasa Inggris yang terdapat dalam buku tersebut.

Seiring dengan kebutuhan bersosialisasi dan rasa ingin tahu anak, kemampuan bahasa sangat pesat pada masa prasekolah. Bahkan anak lebih mudah belajar bahasa selain bahasa ibu jika dibandingkan dengan orang dewasa (Y. V. Uzer, 2019). Stakanova dan Tolsikhina mengatakan mengajarkan Bahasa Inggris pada anak usia dini merupakan sebuah langkah yang tepat (Y. Uzer, 2019). Pembelajaran Bahasa Inggris sangat tepat jika diberikan sedini mungkin. Hal ini ditambahkan oleh Tolsikhina yang dikutip oleh Annisa Rachmani Tyaningsih (2016) mengenai ${ }^{\text {tepatnya }}$ memberikan pelajaran bahasa asing untuk anak usia dini dengan menyatakan beberapa alasan, yaitu, (1) belajar bahasa asing yang dimulai lebih awal akan memiliki waktu yang lebih maksimal untuk belajar. Semakin cepat memulai, akan semakin banyak waktu untuk belajar, (2) saat ini perkembangan linguistik anak usia dini sedang pada tahap yang sangat baik untuk dimanfaatkan sebagai dasar dalam perkembangan linguistik selanjutnya, (3) kemampuan anak usia dini untuk menggunakan bahasa ibunya akan lebih baik jika anak mendapat rangsangan bahasa asing sejak usia dini dan (4) anak akan memiliki kesempatan lebih baik untuk mempelajari bahasa asing yang kedua di sekolah menengah apabila anak yang belajar bahasa asing pertamanya di pra-sekolah atau tingkat sekolah dasar.

Bahasa asing khususnya Bahasa Arab dan Bahasa Inggris diajarkan di sekolah berguna sebagai ilmu pengetahuan, di samping sebagai alat komunikasi. Mempelajari bahasa sebaiknya simulasi sejak dini. Selain bahasa ibu yang harus dikenalkan kepada anak juga perlu dikenalkan Bahasa Arab dan Bahasa Inggris. Pengenalan bahasa asing sejak anak usia dini dapat membuat anak familiar dengan Bahasa Arab dan Bahasa Inggris. Semakin anak familiar dengan Bahasa Arab dan Bahasa Inggris, semakin mudah pula anak tersebut meneruskan pembelajaran bahasa asing pada tingkat yang lebih tinggi. Selain itu, anak akan mendapatkan keuntungan yang lebih dengan belajar Bahasa asing sejak dini, seperti menjadi lebih percaya diri, karena memiliki skill yang lain yang tidak dimiliki oleh anak-anak lain (Muid, 2015). Bahasa kedua atau Bahasa Inggris diajarkan di taman kanak-kanak bertujuan untuk pengenalan dengan berbagai cara pengoptimalan stimulasi bahasa, penyiapan kesiapan anak dalam melanjutkan jenjang pendidikan ke tingkat yang lebih tinggi dimana tantangan kedepannya kedepannya mengharuskan seseorang untuk menguasai Bahasa Inggris (Y. V. Uzer, 2019).

Selaras dengan pendapat Tolsikhina yang dikutip oleh Annisa Rachmani Tyaningsih (2016) bahwa pembelajaran Bahasa Arab dan Inggris dimulai sejak dini sangat memberikan pengaruh yang positif. Anak akan lebih banyak waktu untuk belajar karena jika pembelajaran bahasa asing dimulai sejak usia dini, anak akan meneruskan pembelajaran bahasa asing pada usia selanjutnya dimana perjalanan belajar mereka yang masih panjang dan masing banyak waktu. Apalagi pada zaman sekarang bukan hanya bisa belajar bahasa asing di sekolah saja, di les-les juga memberi fasilitas untuk belajar bahasa asing khususnya Bahasa Arab dan Inggris.

Usia dini memang sangat bagus untuk diberikan stimulasi. Adapun salah satu aspek perkembangan pada usia dini yakni perkembangan bahasa. Perkembangan bahasa sedang berada pada tahap yang memerlukan stimulasi-stimulasi dimana stimulasi tersebut akan berpengaruh pada tahap perkembangan bahasa selanjutnya. Kemampuan penggunakan bahasa pertama atau bahasa ibu akan semakin mahir jika penguasaan Bahasa Arab dan Bahasa Inggris juga semakin diasah sejak dini, karena anak mempelajari Bahasa Arab 
dan Bahasa Inggris melalui Bahasa Indonesia yang menjadi bahasa pertama mereka. Di sekolah tingkat dasar maupun menengah, anak akan memiliki kesempatan lebih baik untuk belajar Bahasa Arab dan Bahasa Inggris karena mereka sudah mendapatkan dasardasar bahasa asing di prasekolah.

Andi Prastowo yang dikutip oleh Lia Mujiarti (2014) menjelaskan bahwa tujuan buku ajar yaitu, menyediakan materi pembelajaran yang menarik bagi siswa dan memberi kemudahan bagi guru dalam menyampaikan materi pembelajaran. Pendapat tersebut menjadi penunjang alasan KB-RA. Perwanida mengajarkan buku materi Bahasa ArabInggris ini. Buku ini memiliki yang materi yang menarik bagi anak usia dini (AUD) karena buku ini menyediakan gambar-gambar yang warna-warni. Anak sangat suka dengan buku-buku yang berisi gambar-gambar yang warna-warni. Selain itu, guru merasa sangat dimudahkan dalam menyampaikan meteri Bahasa Arab dan Bahasa Inggris karena guru tidak perlu lagi untuk menyiapkan materi pembelajaran sebelum pembelajaran dilaksanakan. Penggunaan sumber belajar dan alat bantu yang beragam akan membuat pembelajaran menjadi menarik dan menyenangkan, mempermudah dan mempercepat pemahaman anak, mempertahankan konsentrasi anak lebih lama serta menghambat kejenuhan dalam belajar (Y. V. Uzer, 2019). Dalam jurnalnya, Millah dkk mengutarakan bahwa buku ajar merupakan seperangkat materi substansi pelajaran yang disusun dengan sistematis yang memaparkan keutuhan dari kompetensi yang akan dikuasai oleh siswa dalam kegiatan pembelajaran. Buku ajar dapat membantu guru dalam memberikan atau menyampiakan meteri pembelajaran, sehingga tujuan pembelajaran dapat tercapai (Suwarni, 2015).

\section{SIMPULAN DAN SARAN}

Dari paparan data dan hasil analisis penelitian di atas, dapat penulis simpulkan bahwa hakikat KB-RA. Perwanida Ketintang Surabaya dalam mengajarkan buku materi Bahasa Arab-Inggris dalam pembelajaran bahasa pada anak usia dini kelompok A yakni KB-RA. Perwanida ingin mengembangkan perkembangan bahasa asing anak usia di sesuai dengan tahap usianya, di samping menciptakan suasanya belajar yang menyenangkan dan menarik dengan membuat buku materi Bahasa Arab-Inggris secara mandiri oleh sekolah, dan untuk memudahkan anak untuk belajar Bahasa Arab dan Inggris pada tingkat pendidikan pada jenjang selanjutnya, karena anak sudah merasa familier dengan Bahasa Arab dan Inggris. Di samping itu pula dengan melalui belajar bahasa Arab dan Inggris anak usia dini dapat melatih perkembangan kognitif dengan proses berpikir saat pembelajaran Bahasa Arab dan Inggris berlangsung.

Selain itu, anak juga memiliki lebih banyak waktu untuk belajar Bahasa Arab dan Bahasa Inggris karena pembelajaran bahasa asing dimulai lebih awal, anak akan lebih cepat memahami bahasa yang sedang dipelajarinya yang sangat berpengaruh pada tahap perkembangan bahasa selanjutnya, anak akan lebih mahir dalam menguasai bahasa ibu. Anak akan memiliki kesempatan belajar Bahasa Arab dan Bahasa Ingris lagi di tingkah sekolah dasar ataupun menengah sehingga dapat meningkatkan penguasaan bahasa asing mereka, bukui ini sangat menarik untuk anak usia dini (AUD) yang berada pada tahap perkembangan dan memudahkan guru dalam menyampaikan materi pembelajaran Bahasa Arab dan Bahasa Inggris.

Oleh karena itu, dengan hasil penelitian ini, maka penulis menyarankan dalam pengajaran buku materi Bahasa Arab-Inggris ini harus tetap dilanjutkan dan dikembangkan. Hal ini karena sangat bermanfaat bagi perkembangan bahasa dan kognitif karena dapat menciptakan suasana belajar yang menyenangkan bagi anak usia dini. 


\section{AKNOWLEDGMENT}

Penelitian ini didukung oleh Universitas Islam Negeri Sunan Ampel Surabaya.

\section{DAFTAR RUJUKAN}

Andriana, E., Syachruroji, A., Alamsyah, T. P., \& Sumirat, F. (2017). Natural science Big Book with Baduy local wisdom base media development for elementary school. Jurnal Pendidikan IPA Indonesia, 6(1), 76-80. https://doi.org/10.15294/jpii.v6i1.8674

Anggraini, Wardah; Putri, A. D. (2019). Penerapan Metode Bermain Peran (Role Playing) dalam Mengembangkan Kognitif Anak Usia 5-6 Tahun Wardah Anggraini 1 , Anggi Darma Putri 2. 1(2), 104-114.

Arumsari, A. D., Arifin, B., Rusnalasari, Z. D., \& Inggris, B. (2017). Pembelajaran bahasa inggris pada anak usia dini di kec sukolilo surabaya. 4(2), 133-142.

Chairunnissa, C. (2017). Metode Penelitian Ilmiah Aplikasi dalam Pendidikan dan Sosial. Mitra Wacana Media.

Dardjowidjojo, S. U. A. J. (2012). Psikolinguistik Pengantar Pemahaman Bahasa Manusia. Yayasan Pustaka Obor Indonesia.

Dhieni, N. (2011). Metode Pengembangan Bahasa. Universitas Terbuka.

Lestariningrum, A. (2017). Perencanaan Pembelajaran Anak Usia Dini (Pertama). Adjie Media Nusantara.

Mawarti, S. (2018). Implementasi Media Pembelajaran Visual untuk Perkembangan Kognitif Anak Usia Dini di RA Perwanida Gejugan, Tanjung, Klego, Boyolali Tahun Ajaran 2017/2018. In Высшей Нервной Деятельности. IAIN Surakarta.

Muid, A. (2015). Pentingnya Bahasa Inggris dan Bahasa Arab pada Kurikulum Pendidikan. 14(2), 32-43.

Mujiarti, L. (2014). PENGEMBANGAN BUKU AJAR BERBASIS GAMBAR ALAM DAN BUATAN KELAS V SEMESTER I MI Oleh: Universitas Islam Negeri Maulana Malik Ibrahim.

Nambiar, M. (1993). Early Reading Instruction - Big Books in the ESL Classroom**. XXII(October), 1-9.

Pangastuti, R. (2019). Media Puzzle untuk Mengenal Bentuk Geometri. 1(1), 50-59.

Rujakat, A. (2018). Pendekatan Penelitian Kualitatif (Qualitative Research Approach). Deepublish.

Sa'ida, N. (2018). PEDAGOGI: Jurnal Anak Usia Dini dan Pendidikan Anak Usia Dini. $4(2), 16-22$.

Susanto, A. (2011). Perkembangan Anak Usia Dini Pengantar dalam Berbagai Aspeknya (Pertama). Kencana.

Suwarni, E. (2015). PENGEMBANGAN BUKU AJAR BERBASIS LOKAL MATERI KEANEKARAGAMAN LABA-LABA DI KOTA METRO SEBAGAI SUMBER BELAJAR ALTERNATIF BIOLOGI UNTUK SISWA SMA KELAS X. 6(2), 86-92.

Tyaningsih, A. R. (2016). PEMBELAJARAN BAHASA INGGRIS PADA ANAK USIA DINI. 3(1), 74-82.

Uzer, Y. (2019). IMPLEMENTASI PEMBELAJARAN BAHASA INGGRIS ANAK. 2(1).

Uzer, Y. V. (2019). Strategi belajar bahasa inggris yang menyenangkan untuk pendidikan anak usia dini. 2(1).

Yuli, \& Rachmawati, S. F. A.-M. W. N. A. et al. (2014). ENGLISH IN PRESCHOOL CURRICULUM : A DESCRIPTIVE STUDY OF THE TEACHING OF ENGLISH AS AN INTRA-SCHOOL CURRICULUM IN. 14(2), 193-204. 


\section{AUTHOR}

Imam Syafi'i dilahirkan di Kediri Jawa Timur tanggal 20 November 1970, anak ke 6 dari 6 bersaudara, Pendidikan yang ditempuh: SDN Kediri, MTs , MA dan Pesantren Gresik, S1, IAIN Sunan Ampel Surabaya, S2, S3 UIN Sunan Ampel Surabaya. Dosen di Program Studi Pendidikan Islam Anak Usia Dini Fakultas Tarbiyah dan Keguruan UIN Sunan Ampel Surabaya.

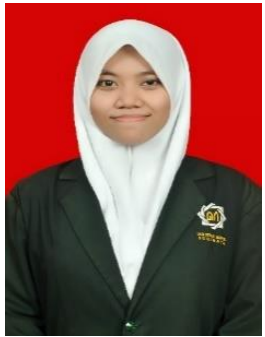

Alfian Nuril Laily Abror dilahirkan di Bangkalan Jawa Timur tanggal 4 November 1997, anak ke 3 dari 3 bersaudara. Pendidikan dasar dan menengah telah ditempuh di kampung halamannya di SDN Burneh 01, SMPN 2 Bangkalan dan SMAN 1 Bangkalan. Pendidikan berikutnya ia tempuh di Program Studi Pendidikan Islam Anak Usia Dini Fakultas Tarbiyah dan Keguruan UIN Sunan Ampel Surabaya. Semasa mahasiswa aktif dalam organisasi kemahasiswaan dan karang taruna. 